Article

\title{
Development and Piloting of Sustainability Assessment Metrics for Arctic Process Industry in Finland-The Biorefinery Investment and Slag Processing Service Cases
}

\author{
Roope Husgafvel $^{1, *}$, Kari Poikela ${ }^{2}$, Juha Honkatukia ${ }^{3}$ and Olli Dahl ${ }^{1}$ \\ 1 Clean Technologies Research Group, Department of Bioproducts and -systems, \\ School of Chemical Technology, Aalto University, Espoo 00076 AALTO, Finland; olli.dahl@aalto.fi \\ 2 Digipolis-Kemi Technology Park, Cluster of Arctic Industry and Circular Economy in Lapland, \\ Kemin 94600, Finland; kari.poikela@digipolis.fi \\ 3 VTT Technical Research Center of Finland, Espoo 02150, Finland; juha.honkatukia@vtt.fi \\ * Correspondence: roope.husgafvel@aalto.fi; Tel.: +358-400-970402
}

Received: 9 August 2017; Accepted: 18 September 2017; Published: 22 September 2017

\begin{abstract}
Regionally, there has been a lot of focus on the advancement of sustainable arctic industry and circular economy activities within process industry in the Finnish Lapland. In this study, collaboration between university and industry was established facilitated by regional development actors to develop and pilot test a sustainability assessment approach taking into account previous work in this field. The industry partners in this study were a biorefinery investment in the first case and a slag processing service in the second case. As a result of the joint efforts, novel sets of environmental and economic sustainability assessment indicators and associated sub-indicators were developed and the existing set of social indicators was updated. Moreover, environmental and social sustainability assessments were implemented in the biorefinery case accompanied by a separate evaluation of regional economic impacts. In the slag processing case, environmental, economic and social sustainability were assessed. The results of the sustainability assessments indicated very good level of overall performance in both cases. However, specific elements that contributed to lower level of performance included lack of specific sustainability management and reporting approaches and need for better performance in supply chain sustainability, monitoring of greenhouse gas emissions, life cycle thinking and circular economy training. The expected effects of the planned investment on the regional economy were very positive based on the results of the evaluation.
\end{abstract}

Keywords: sustainability; metrics; indicator; industry; arctic; circular economy

\section{Introduction}

Globally recognized sustainable development goals [1] encompass, for example, sustainable management and efficient use of natural resources, sustainable production and industrialization, increasing adoption of clean and environmentally sound technologies and combating climate change. In this study, the development of the sustainability index and associated key indicators and sub-indicator sets are based on the holistic idea that sustainability assessment should cover environmental, economic and social dimensions. The development work derives from diverse global sources taking into account multiple processes involving numerous stakeholders. The biorefinery investment case study focuses on the planning phase whereas the slag processing service is a running service provided for process industry. The biorefinery investment is regionally significant and the slag processing service has importance in the context of industrial circular economy development through novel use and minimization of waste. Previous studies have addressed the need to develop integrated 
approaches to sustainability assessment in process industry to support informed decision-making [2-4]. Only few international sustainability measurement efforts have applied an integral approach taking into account environmental, economic and social aspects [5].

Additionally, previous studies have concluded that corporate sustainability requires integrative measurement and management of sustainability issues instead of isolated application of various tools [6,7]. Sustainability performance indicators can be applied to the identification and assessment of key issues [6] and sustainability assessment and management accounting, control, and reporting should be integrated [7]. Moreover, sustainability and supply chain management should be integrated including involvement of all stakeholders, development of performance measures and application of supplier partnerships standards. Further research is needed on supply chains in low-income countries and effective integration of sustainability into the operations of companies requires action beyond corporate boundaries [8].

For example, it has been noted that transforming the existing environmental assessment tools in the building sector into sustainability assessment tools is likely to be very challenging and that it is necessary to focus on all environmental, economic and social aspects. In addition, it is important to address future requirements and consider the value of the tools for decision-making taking into account cultural factors and different legislative conditions [9]. A previous study has also suggested that sustainability assessment in the field of built environments tend to lack sufficient focus on social sustainability and noted that this situation can be improved though the consideration of social improvement in the short and long term including the application of social sustainability improvement goals, criteria and indices [10]. Another study also noted the need to address social, economic and cultural indicators in the context of sustainable buildings in addition to environmental indicators. Additionally, this study presented a methodology (Sustainable Building Tool) to evaluate overall sustainability performance and to support sustainable design encompassing sustainability indicators for the following dimensions: environment, society and economy [11].

Circular economy development is given particular emphasis on this study because of its timely importance at the EU, national and regional levels. Contemporary EU policy goals highlight the importance of circular economy encompassing focus on sustainability considerations, life cycle thinking, whole system approaches, resource efficiency and resource productivity in industry [12-14]. In the Finnish Lapland, there has been a lot of effort to establish a functioning cluster of arctic industry with emphasis on circular economy development, sustainability and industrial ecosystems and symbiosis [15-18]. National efforts highlight, for example, the advancement of more sustainable societies and businesses considering economic, environmental and societal aspects [19]. Important focus areas encompass, for example, the value of production side streams and creation of cooperation between industry and small and medium-sized enterprises [20].

Previous studies on circular economy have suggested that it can advance sustainable development, inter-industry integration and cleaner production [21]. Similarly to many sustainability assessments, it has been noted that performance indicators can be applied to the identification and assessment of key aspects of circular economy development [22]. In addition, the transition towards circular economy is about engagement of all societal actors based on an interdisciplinary framework and addressing problems such as inefficient resource use, environmental impacts and social inequity [23].

\section{Aims of the Study}

This study focused on capacity-building for and piloting of sustainability assessment in arctic process industry covering two cases studies: (1) the biorefinery investment (planning phase) and (2) a slag processing service (running service). Both cases were demand-side driven and based on on actual regional need for sustainability assessment. In this study, slag refers to process industry residue (separated from stainless steel manufacturing process) and process refers to te refining of the slag to separate the remaining metal elements from stony materials (metals go back to production and stone materials are further processed). The overall aim of the Boreal Bioref biorefinery case was to develop 
and pilot test environmental and social sustainability assessment metrics building on earlier research on sustainability performance metrics. In addition, a separate evaluation of regional economic effects was carried out to assess the economic dimensions of the planned investment. This case focused on the planned biorefinery in Kemijärvi in Northern Finland covering all the planned factory operations and activities. The specific objectives of this case study were:

- To develop a novel set of environmental sustainability assessment indicators and sub-indicators;

- To update the previously developed social sustainability assessment indicators and sub-indicators;

- To carry out pilot sustainability performance assessment using the developed and updated sets of environmental and social sustainability assessment indicators and sub-indicators;

- To evaluate the effects of the planned investment on the regional economy in Lapland, considering the linkages between sectors and local markets.

The overall aim of the slag processing service case was to develop and pilot test sustainability performance and assessment metrics. The service is provided by the Tapojärvi company located in Northern Finland and it produces slag-based end-products and thus contributes to the minimisation of slag waste and promotes the use of slag as a valuable raw material. The specific objectives of this study were:

- To develop a novel set of economic sustainability assessment indicators and sub-indicators encompassing a specific indicator/sub-indicators for circular economy aspects;

- To update (if additions or removals are necessary due to sector/plant/process specific reasons) the environmental and social sustainability assessment sub-indicators developed in the first case;

- To carry out pilot sustainability performance assessment using the developed and updated indicator sets.

\section{Material and Methods}

\subsection{Sustainability Assessment Index and Indicators}

The Boreal Bioref biorefinery is scheduled to be in operation in 2020 and all the permits will be acquired by early 2018. The biorefinery will include a pulp plant, Micro Crystalline Cellulose (MCC) production facility, biogas production facility and energy production units [24]. This planned investment is regionally significant and is a good example of new development in the biorefinery sector in Finland. The Tapojärvi slag processing service is a running service designed for large scale industrial clients [25]. This kind of processes are considered important in the context of circular economy development within process industry due to their contribution to waste minimisation and use of materials that were previously considered to be waste as valuable raw material. The biorefinery case encompassed environmental and social sustainability assessments and associated development work and evaluation of regional economic effects whereas the slag processing service case focused on the assessment of environmental, social and economic sustainability including associated development work.

The sustainability assessment framework applied in this study was based on the results of previous research and development efforts [26-28]. The framework was built on a sustainability index and associated indicators and sub-indicator sets. From the very beginning of the development work the idea was to support plant level sustainability performance management and assessment through an easily applicable decision-support method. The applied index encompassed environmental, economic and social components accompanied by legal aspects in each component.

Thus, the Sustainability-index $=A_{L}+B_{L}+C_{L}$

- $\quad$ Environmental aspects (A)

- $\quad$ Economic aspects (B)

- $\quad$ Social aspects $(C)$ 
- $\quad$ Legal aspects (L).

The index operates in a way that a total score is also calculated for each dimension to allow for specific examination of economic, social and environmental sustainability performance. In the next phase, the total score of each sustainability dimension (A, B and C including legal aspects in each element) is added together to produce the final score for overall sustainability performance. The actual development work and scoring method are briefly explained in the following sections.

In the initial development phase, the characteristics and operating principles of key global initiatives (e.g., the UN Global Compact and the Global Reporting Initiative, ISO 26000, the Dow Jones Sustainability Index and the RobecoSAM Corporate Sustainability Assessment) and existing company practices of both sustainability management and reporting were reviewed to ensure that the proposed index and key indicators cover all internationally recognized key aspects. In addition, all key EU and Finnish policy and strategy documents in the field of circular economy were reviewed during this study to develop a specific economic indicator on that topic and to update other indicator sets. The developed sustainability assessment indicators and the number of associated sub-indicators are presented in Table 1 and examples of sub-indicators addressing environmental impacts are presented in Appendix A.

Table 1. Sustainability assessment indicators and the number of sub-indicators.

\begin{tabular}{|c|c|c|c|c|c|}
\hline \multicolumn{2}{|c|}{ Environmental Indicators } & \multicolumn{2}{|c|}{ Social Indicators } & \multicolumn{2}{|c|}{ Economic Indicators } \\
\hline Indicator & $\begin{array}{c}\text { Number of } \\
\text { Sub-Indicators }\end{array}$ & Indicator & $\begin{array}{c}\text { Number of } \\
\text { Sub-Indicators }\end{array}$ & Indicator & $\begin{array}{c}\text { Number of } \\
\text { Sub-Indicators }\end{array}$ \\
\hline Air emissions & $5^{1}$ & Location $^{2}$ & 6 & Leadership and strategy & 19 \\
\hline Water emissions & 8 & Supply chain & 19 & $\begin{array}{l}\text { Management and } \\
\text { reporting }\end{array}$ & 19 \\
\hline Solid residues & 6 & $\begin{array}{c}\text { Social } \\
\text { innovations }\end{array}$ & 8 & Economic performance & 10 \\
\hline $\begin{array}{l}\text { Process and } \\
\text { production } \\
\text { efficiency }\end{array}$ & 17 & $\begin{array}{l}\text { Labour } \\
\text { practices }\end{array}$ & 40 & Economic impacts & 10 \\
\hline Transport & 14 & $\begin{array}{l}\text { Training and } \\
\text { skills }\end{array}$ & 14 & Investments and markets & 15 \\
\hline $\begin{array}{l}\text { Greenhouse gas } \\
\text { emissions }\end{array}$ & 7 & Reporting & 14 & Circular economy & 20 \\
\hline $\begin{array}{l}\text { Management and } \\
\text { reporting }\end{array}$ & 29 & $\begin{array}{l}\text { Health and } \\
\text { safety }\end{array}$ & 16 & Supply chain & 10 \\
\hline $\begin{array}{l}\text { Environmental } \\
\text { innovations }\end{array}$ & 18 & \multirow{5}{*}{ Legal aspects } & \multirow{5}{*}{29} & Code of conduct & 10 \\
\hline \multirow[t]{2}{*}{$\begin{array}{l}\text { Leadership and } \\
\text { strategy }\end{array}$} & 14 & & & $\begin{array}{l}\text { Operational environment } \\
\text { and risks }\end{array}$ & 12 \\
\hline & & & & Research and development & 10 \\
\hline \multirow[t]{2}{*}{ Legal aspects } & 49 & & & $\begin{array}{c}\text { Economic innovations and } \\
\text { competitiveness }\end{array}$ & 10 \\
\hline & & & & Legal aspects & 23 \\
\hline
\end{tabular}

Note: ${ }^{1}$ The sub-indicators were the monitoring/awareness of (1) $\mathrm{CO}_{2}$, (2) $\mathrm{SO}_{2}$ and (3) NOx emissions levels and (4) dust stack load and (5) heavy metal stack load ( $\mathrm{kg} /$ tonne of product); ${ }^{2}$ The Worldwide Governance Indicators [29] aggregate indicators and project country data from 2014 were used to measure performance in the location indicator of the social indicator set. The percentile scores for Finland were transformed into scores between 5 and -5 (e.g., -5 equals to $100 \%$ ).

The updating of the sustainability indicator and sub-indicator sets was implemented through review of literature, latest research findings and global initiatives, frameworks and instruments in the first phase. Current process industry approaches to sustainability management and assessment and to corporate social responsibility were also reviewed using online sources. The reviewed sources included many global processes with multiple stakeholders. Thus, the selected indicators and sub-indicators reflect a broad range of contemporary perspectives on all dimensions of sustainability. Following that initial phase, the final sets for both cases were developed and chosen in the workshops (one 
workshop for each dimension of sustainability) jointly with company representatives facilitated by regional actors (The Kemi Digipolis company in two cases and the Centre for Economic Development, Transport and the Environment in the biorefinery case) who managed the overall project within which this study was implemented (see acknowledgements). The Kemi Digipolis company is a regional actor which provides services for companies. In the biorefinery case, a novel set environmental indicators and sub-indicators was developed and the social indicator set was updated. A novel set of economic sustainability assessment indicators were created in the slag processing service case encompassing specific focus on circular economy aspects. Compared to the initial set of social indicators [27], the number of sub-indicators was increased in the social innovations, labour practices, training and skills, reporting and health and safety categories. The new sub-indicators formulated as questions were:

- Social innovations indicator: (1) Have you made any new innovations or initiatives in the field of continuous improvement of employee well-being and satisfaction, maintenance of competence and attraction of new competence? (2) Have you made any new innovations or initiatives in the field of social risk assessment and management covering the whole supply chain, full product/service life cycle and markets/customers? and (3) Have you made any new innovations or initiatives in the field training, education or competence development?

- Labour practices indicator: (1) Can employees influence the timing of their vacations (e.g., employees with a family and single parents)? (vacation category), (2) Does the factory/company have an official system for complaints about labour practices, working conditions or terms of employment? (3) Do you monitor the well-being and satisfaction of employees and the attractiveness of the working place to maintain and attract competent people? (monitoring category), (4) Can employees influence their working time or shifts at the yearly, monthly, weekly or daily levels? (5) Is it possible to do less working hours in particular cases (e.g., childcare, health reason or commuting) and (6) are working times, shifts and possible night shifts and various challenging tasks divided equally and considering staff opinions at the yearly, monthly or weekly levels? (working time category).

- Training and skills indicator: (1) Do you encourage the sharing of best practices? (training category).

- Reporting indicator: Does your social sustainability reporting cover (1) national and international labour and human rights standards? (2) the whole supply chain (including suppliers and their suppliers)? (3) the continuous development of employee training and competence? (4) the identification, engagement and inclusion (dialogue) of local communities and key stakeholders and interest groups? and (5) communication about local risks, changes, responsibilities and impacts? (local communities category).

- Health and safety indicator: (1) are occupational health care appointments and examinations included in the working hours?

The company representatives in the biorefinery case included the CEO (chairman), the manager responsible for the environmental impact assessment process and a local expert with long-term experience from pulp and paper industry who were also supported by other members of the management and planning team. In the slag processing service case, the company representatives included the research and development manager, the quality manager and the human resources manager who were supported by other staff members.

The developed indicator and sub-indicator sets were formulated into questionnaire sheets and answered by the company representatives (first independently as much as possible and then in workshops). In the biorefinery case, the sets of environmental and social sustainability indicators were used and in the slag processing service case those same sets were utilized accompanied by the developed novel set of economic sustainability indicators and sub-indicators. No environmental or social indicators or sub-indicators were added or removed in the workshops preceding the slag processing service assessment (no sector/plant/process related reasons to made additions or removals were identified). The report on the Kemijärvi biorefinery environmental impact assessment 
programme [30] including e.g., references about best available techniques (BAT) and evaluations and the best available techniques Reference documents (BREFs) for the production of pulp, paper and board (including BAT conclusions) was taken into account in the assessment of environmental sustainability.

The Sustainability-index and associated environmental, economic and social indicators accompanied by legal aspects was applied to assess sustainability in both cases. The method was a simple scoring based on received answers to questionnaire sheets from the company representatives. The answer were also checked and discussed in the follow-up workshops to ensure that both the questions and answers were understood properly. The scoring was based on a scale from 5 (lowest level of performance) to -5 (best level of performance) in both the total score and single indicators/sub-indicator scores (Table 2). Thus, the total score is the average score based on the score of each indicators and the score of each indicator is based on the average score of the associated set of sub-indicators (the score is always something between -5 and 5). Any score between 0 and -5 was marked by green column to demonstrate a positive score and any score between 0 and 5 was marked with a red column to demonstrate a negative score.

Table 2. Explanation of the sustainability-index scoring.

\begin{tabular}{ccl}
\hline Questionnaire Sheet Answer & Score & \multicolumn{1}{c}{ Explanation } \\
\hline Yes & -5 & $\begin{array}{l}\text { The right/correct answer for that specific question (depends on the } \\
\text { formulation of the questions in the particular sub-indicator) } \\
\text { indicating (1) that the matter is duly addressed/managed and } \\
\text { (2) best performance in the field of that sub-indicator and } \\
\text { competent management }\end{array}$ \\
\hline Yes/Not known & $\begin{array}{l}\text { This answer indicates (1) that the matter is partially addressed and } \\
\text { (2) fair/good performance level requiring management attention }\end{array}$ \\
\hline Not known & $\begin{array}{l}\text { This question cannot be answered due to lack of information/data } \\
\text { indicating neutral performance (not positive or negative in } \\
\text { both cases) }\end{array}$ \\
\hline No/Not known & $\begin{array}{l}\text { This answer indicates (1) that the matter is not addressed and that } \\
\text { there is some relevant information/data missing and (2) low level of } \\
\text { performance requiring management attention }\end{array}$ \\
\hline No & $\begin{array}{l}\text { The wrong/incorrect answer for that specific question (depends on } \\
\text { the formulation of the questions in the particular sub-indicator) } \\
\text { indicating (1) that the matter is not addressed/managed and } \\
\text { (2) poor/lowest level of performance in the field of that } \\
\text { sub-indicator requiring urgent management attention }\end{array}$ \\
\hline
\end{tabular}

The following answers (Table 2) were used: (1) yes, no or not known/partially known supported by numerical figures in some sections for additional information and (2) selection of e.g., A, B or C (multiple choice questions). There was one question for each sub-indicator in all the developed sets. The chosen approach is qualitative and the index quantifies the answers using scoring. It has limitations such as the relative roughness of the scoring and lack of numerical data for many aspects of e.g., environmental performance. The chosen approach was developed collaboratively to address a specific problem (holistic assessment of plant level sustainability) and it contributes to both sustainability management and assessment. It can also serve as a basis for further specific assessments (e.g., environmental, economic and social impact and life cycle assessments).

\subsection{Evaluation of Regional Economic Effects}

In the biorefinery case, the evaluation of the effects of the planned Borealis biorefinery on the regional economy in Lapland, the northernmost Finnish landscape was carried out using a regional, computable general equilibrium model [31]. This is not the first time Lapland has become under such scrutiny, neither it is Lapland the sole landscape to have been so studied. Rather, CGE modelling has 
served as one of the most important methodologies in advising the planners of regional employment and education policies in Finland for close to a decade. It was part of the 2010 Peer Review process of the EU Commission Employment, Social Affairs and Inclusion Mutual Learning Programme; and forms part of EU Joint Action on Health Workforce tool kit [32,33]. As is typical for this methodology, the effects of the project are evaluated with respect to a dynamic baseline scenario, which here bases on a recent anticipation study on the long run development of the Finnish economy. Investment in the Borealis biorefinery is large even in a national setting, but here, the focus is on Lapland's regional economy. For the simulation of the effects of the new plant, three central assumptions were made:

(1) The construction of the plant commences in 2017, tripling forest sector investment in Lapland compared to the baseline forecast.

(2) The plant becomes operational in 2019, employing 180 workers directly, and increasing the demand for lumber in Lapland by 18 per cent compared to baseline; most of the plant's production is exported.

(3) The plant will be able to get most of its raw material from local forestry, currently producing under capacity, increasing the output of Lapland's forestry by some 8 per cent.

We also assumed that Lapland's labour markets have some slack in the next few years-not an unrealistic assumption given the high rates of unemployment. This implies that the plant will mostly be creating new jobs, even though it is clear there will be some competition for labour within the region.

\section{Results}

\subsection{The Biorefinery Investment Case}

The total score for environmental sustainability was -3.64 (Figure 1) and the total score for social sustainability was -4.73 (Figure 2). The best score is -5 and thus both results are very good. However, environmental sustainability performance was lower in the following areas: (1) knowledge and monitoring of greenhouse gas emissions; (2) some areas of energy efficiency; (3) knowledge and follow-up of the operational environment (e.g., management of change); (4) life cycle thinking and assessment as a part of management and reporting and (5) knowledge and monitoring of the supply chain and the operations of suppliers. Social sustainability performance was lower in the following areas: (1) knowledge and continuous monitoring of the supply chain; (2) the operations and performance levels of various suppliers; (3) innovative approach to and new initiatives for the comprehensive assessment and management of social risks covering the whole supply chain, markets and customers; (4) life cycle thinking in risk management and reporting and (5) development of the flexibility of working hours and production reward systems.

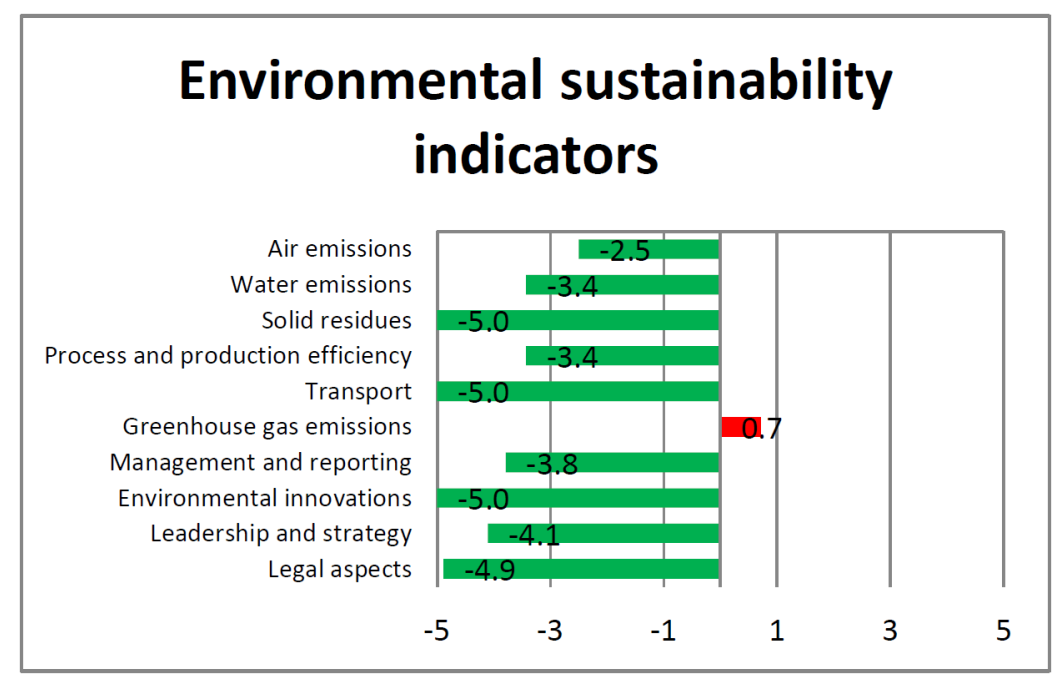

Figure 1. Environmental sustainability indicators. 


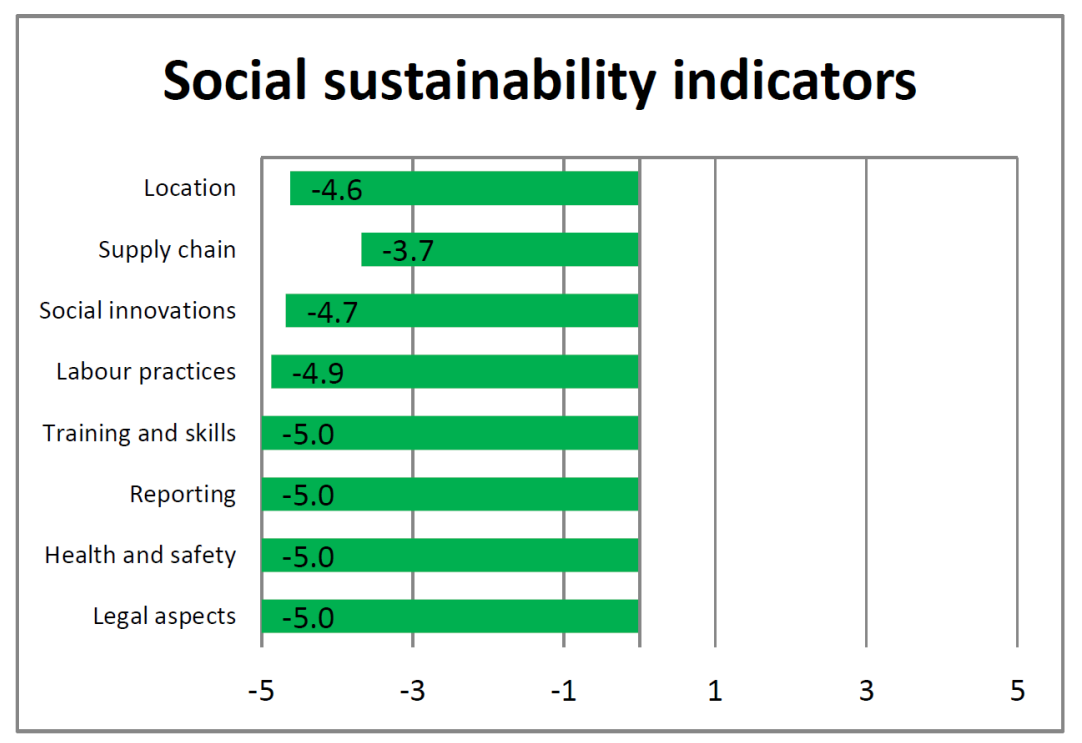

Figure 2. Social sustainability indicators.

The results of the evaluation of the regional economic effects indicate that the planned investment would have notable positive effects on the regional economy. The volume of industrial output in Lapland increases by some four per cent compared to baseline (Figure 3). Output of agriculture and forestry increases by six and a half per cent compared to baseline when the plant becomes operational. Construction, trade and services enjoy a short boom during the investment period Transport and service sectors expand permanently once the plant becomes operational. The expansion of the regional economy creates demand for trade and services in the long run. In monetary terms (Figure 4), the value of industrial output (in current prices) is some 260 million euros higher than in baseline by 2030, that of forestry some 60 million euros, and the value of trade and construction also by tens of millions of euros. In terms of value added, the effects on the industrial sector dominate, but transport and other services, construction and trade also grow by more than two per cent. The new plant creates some 700 new jobs in Lapland (Figure 5). Initially, about half of the new jobs are in construction, but in the longer run, apart from the plant itself, new jobs are created in mostly in forestry, transports and trade.

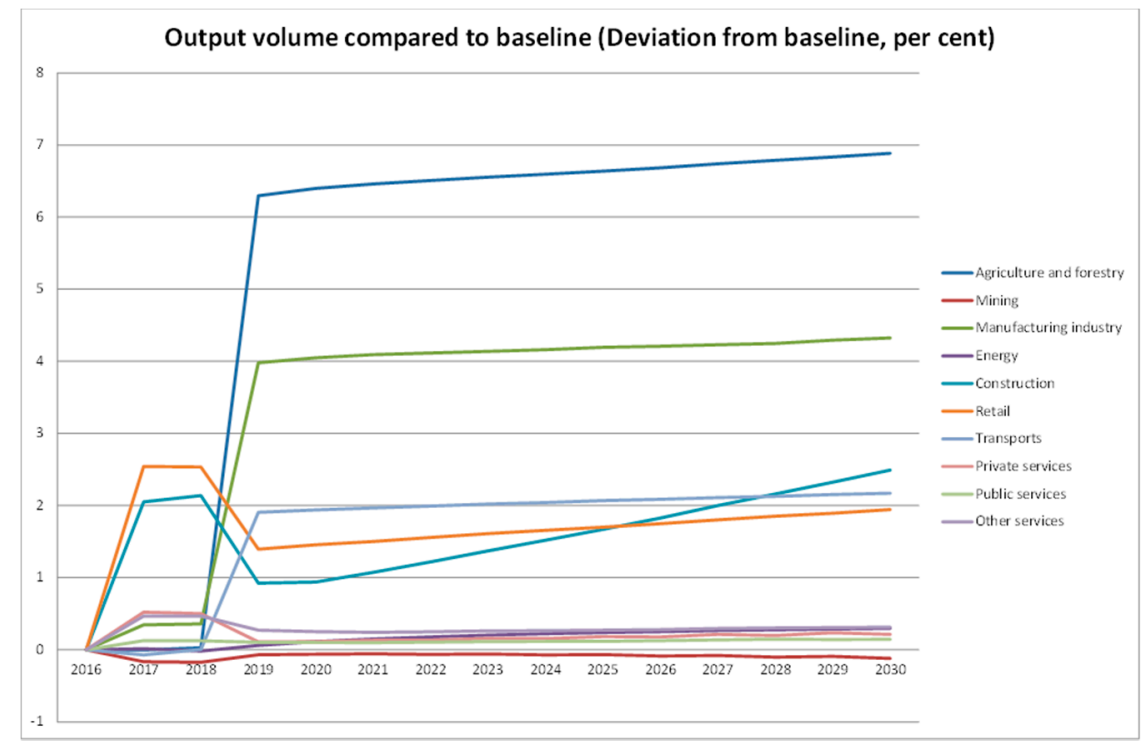

Figure 3. Output compared to baseline. 


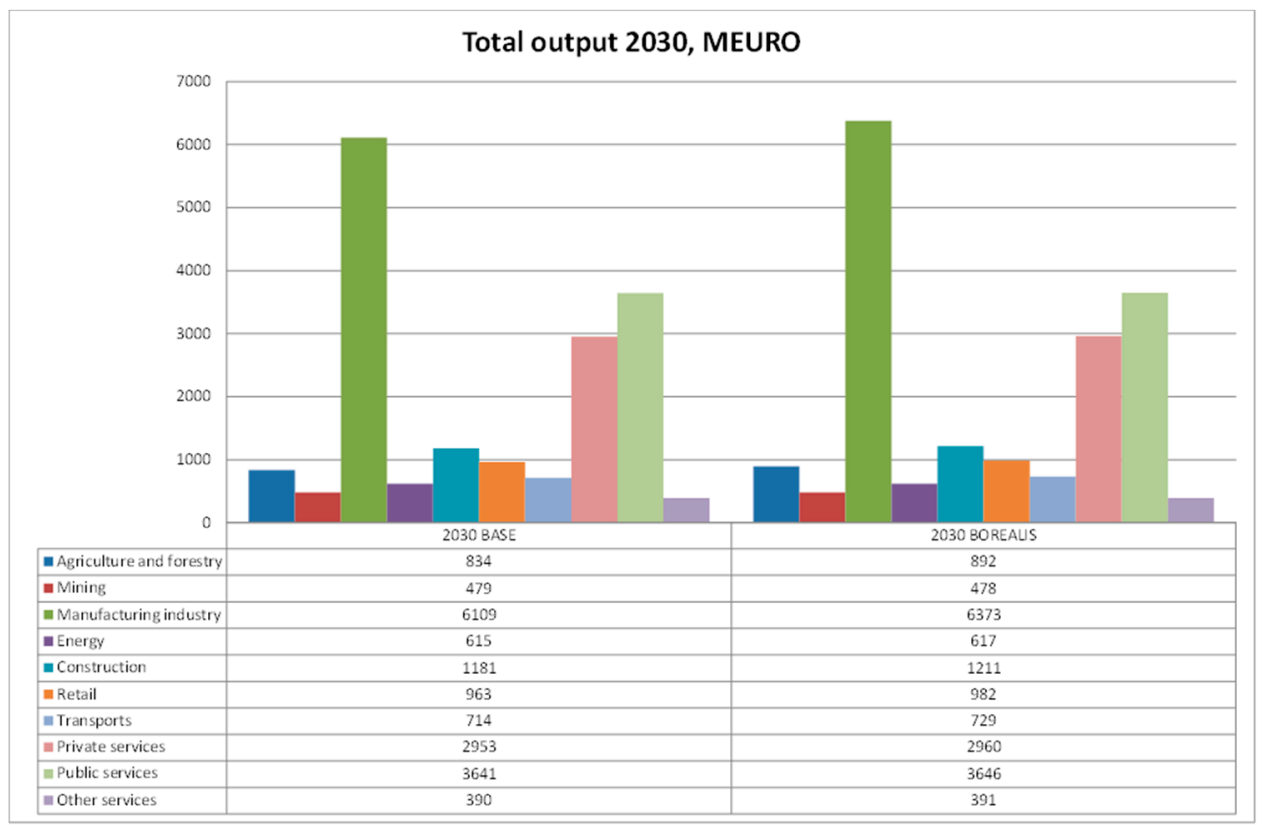

Figure 4. Total output in monetary terms.

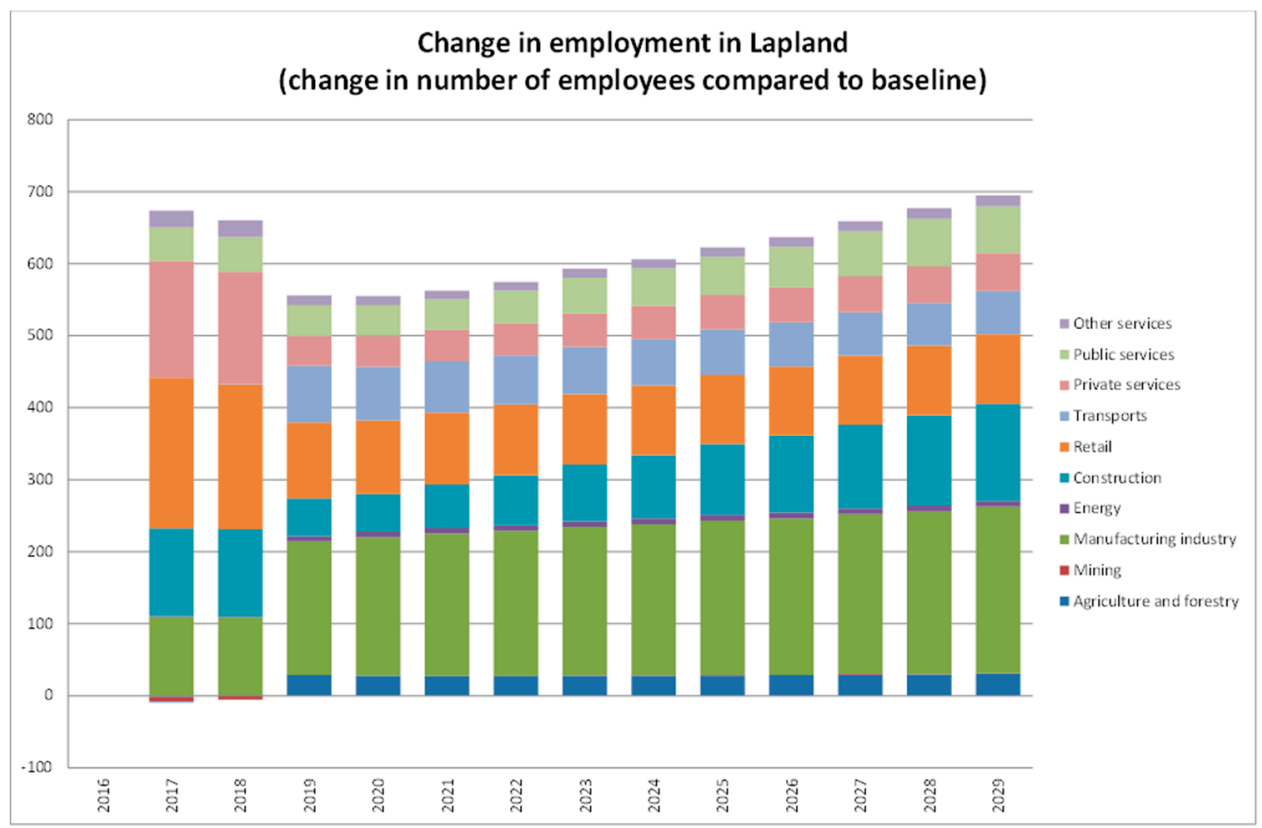

Figure 5. Change in employment in Lapland.

\subsection{The Slag Processing Service Case}

The overall score for the environmental sustainability was -4.13 (Figure 6) which indicates very good level of performance. However, environmental sustainability performance was lower in the following areas: (1) air emissions (focus on monitoring and assessment); (2) transport (focus on monitoring and assessment of emissions); (3) environmental impacts of energy transfer; (4) development of environmental product declarations and promotion of new innovations (customers also play a key role in adoption of cleaner technologies) and (5) application of the same environmental strategy and approaches in all market areas. Regarding legal aspects, it is noteworthy that the potential implications of the proximity of water systems, waste management requirements (e.g., 
circular economy developments) and the possible need for monetary preparation for potential closure of operations lowered the scores.

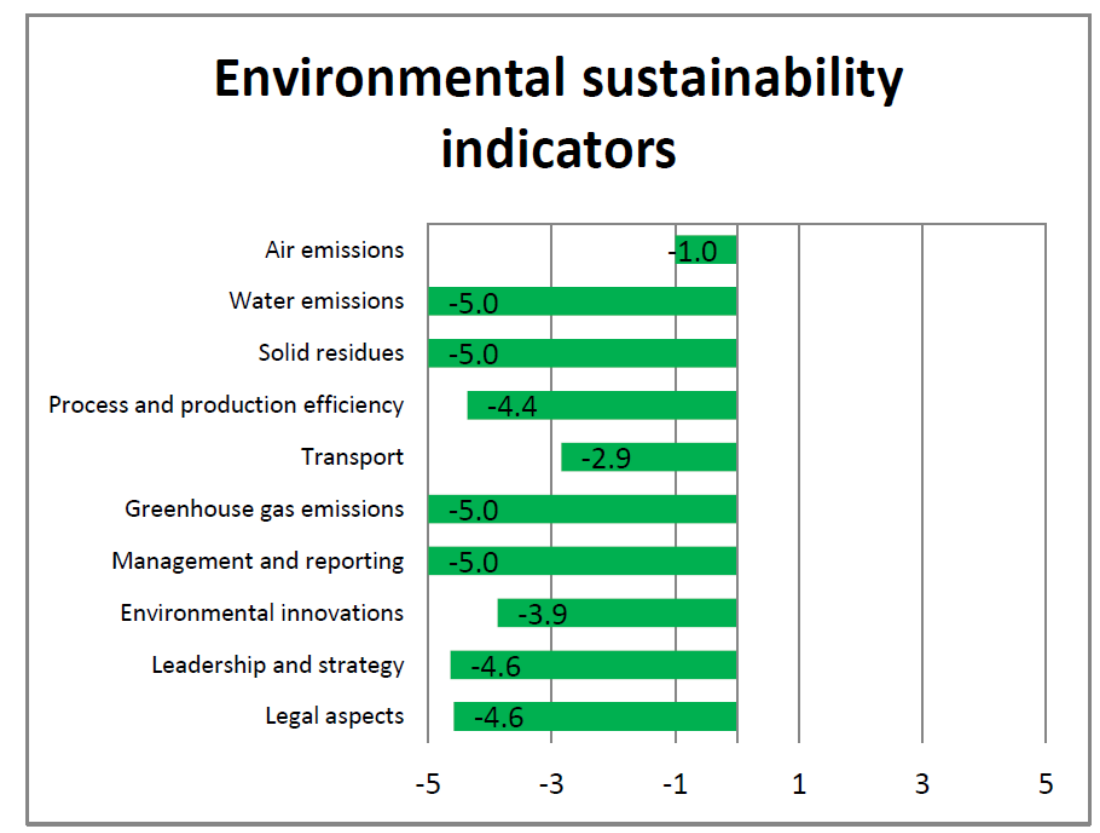

Figure 6. Environmental sustainability indicators.

The overall score for the economic sustainability was -3.95 (Figure 7), which also indicates very good level of performance. Economic sustainability performance was lower in the following fields: (1) code of conduct; (2) specific sustainability strategy; (3) application of sustainability management and assessment tools; (4) circular economy training and incentives; (5) supply chain information, (6) research and development in the field of sustainability and (7) addressing the matter of unfair competition situations created by international, EU level and national legal environments.

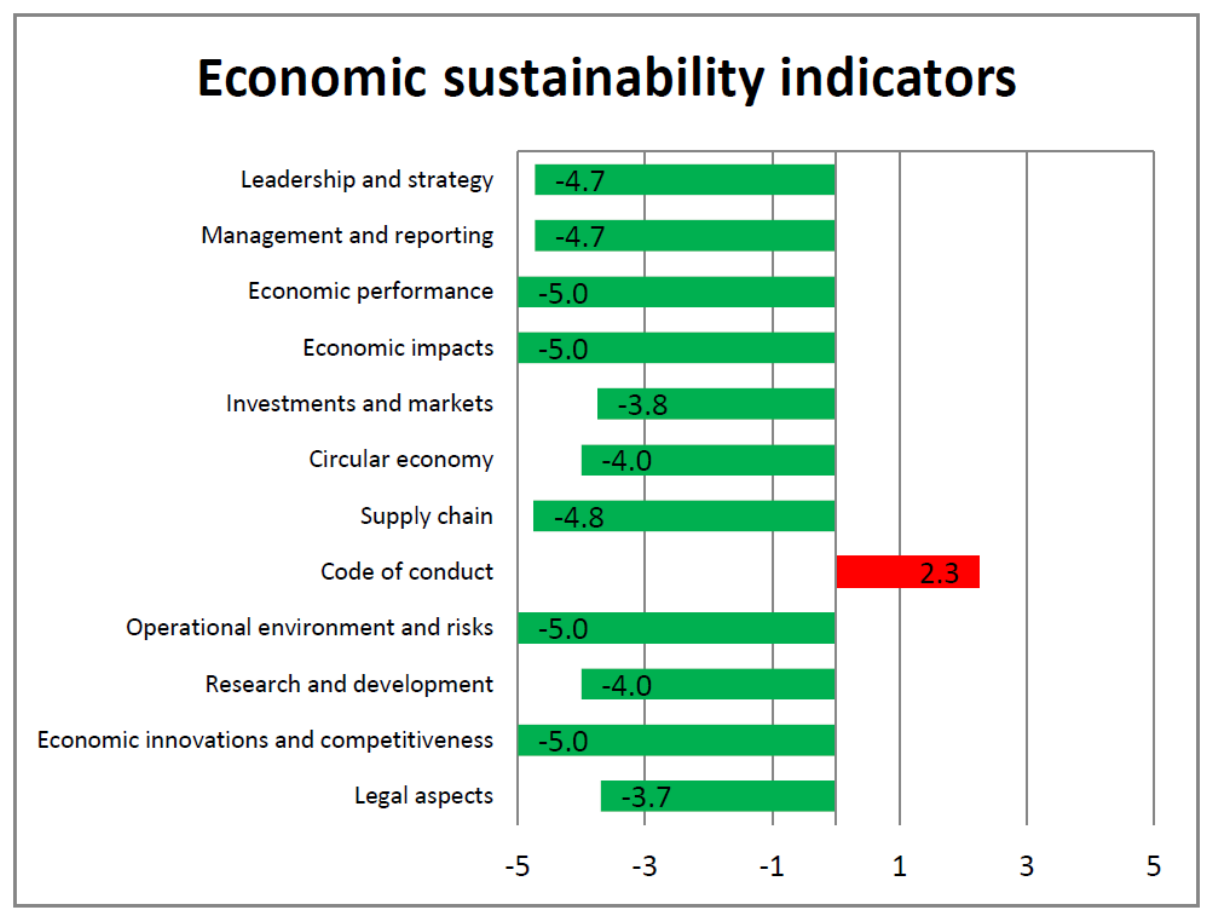

Figure 7. Economic sustainability indicators. 
The overall score for social sustainability was -3.82 (Figure 8 ), which indicates very good level of performance. Social sustainability performance was lower in the following fields: (1) reporting (excluding local community issues that were fully covered); (2) assessment of supply chain social risks and (3) employee commitment to the code of conduct (by signing the code).

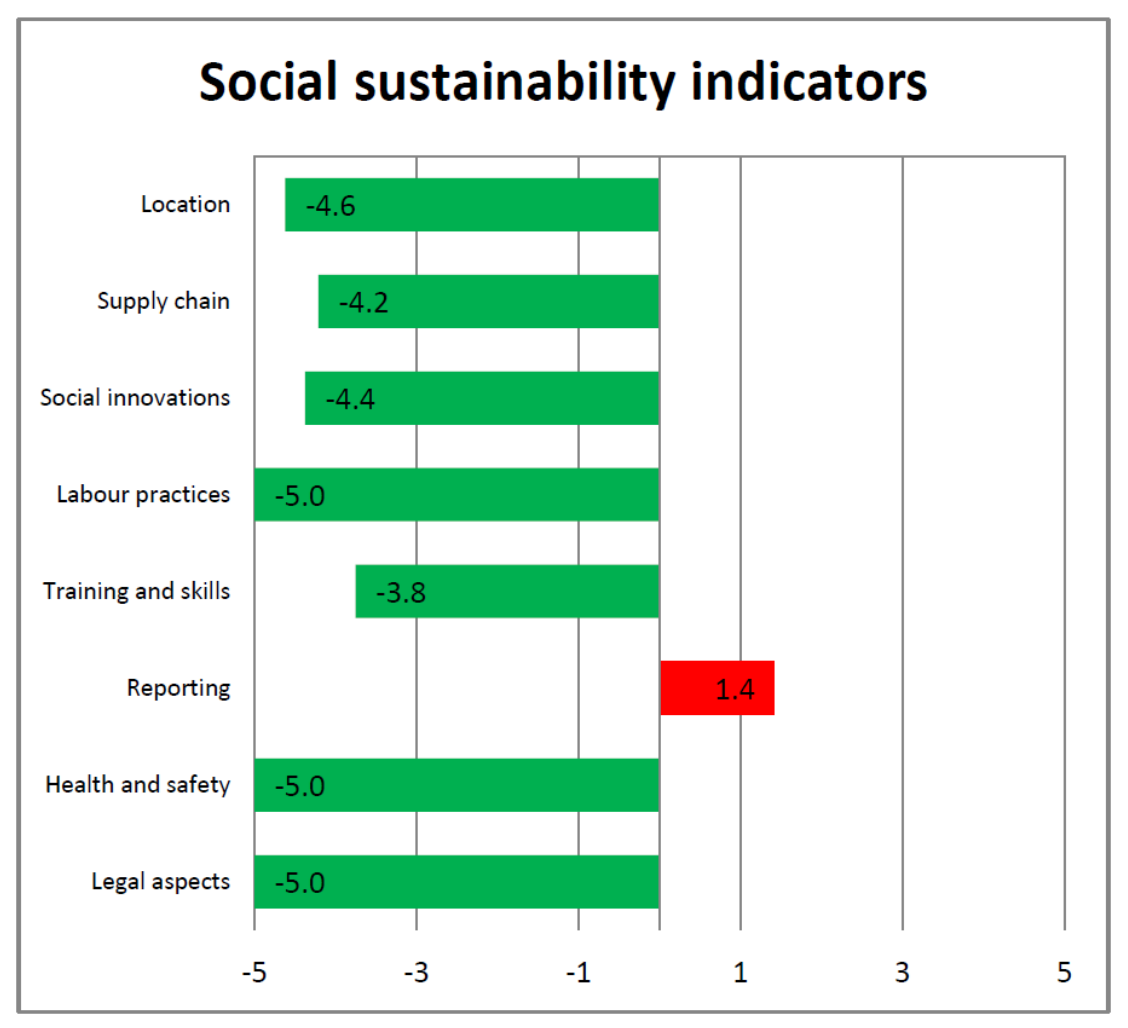

Figure 8. Social sustainability indicators.

\section{Discussion}

Interestingly, the results of both case studies indicate that performance in the field of greenhouse gas emissions (knowledge, monitoring and assessment), supply chain sustainability and code of conduct is lower than in other areas. In addition, there are some similarities in supply chain sustainability and code of conduct aspects as indicated by our previous study on social sustainability assessment [28]. Previous studies have noted that sustainability and supply chain management should be integrated including involvement of all stakeholders, development of performance measures and application of supplier partnerships standards [8]. Locations also matter because business is global in nature and the operational environments in various locations varies a lot. It has been noted that further research is needed on supply chains in low-income countries and on effective integration of sustainability into the operations of companies beyond corporate boundaries [8].

In general, previous studies on the sustainability assessment methodology have concluded that the three dimensions of sustainability should be applied in assessments in addition to life cycle assessment to support informed decision-making [34-36] and that several complementary sustainability indices could be applied due to theoretical or methodological differences between current indices [37]. Previous studies have also addressed the need to develop integrated approaches to sustainability assessment in process industry to support informed decision-making [2-4]. Only few international sustainability measurement efforts have applied an integral approach taking into account environmental, economic and social aspects [5]. In previous studies, it has been noted that sustainability assessment of biorefineries requires the application of multiple indicators to support associated decision-making processes [38] and environmental, economic and social sustainability assessment indicators can be 
applied to the assessment of renewable energy technologies [39]. Sustainability assessments encompass economic and social dimensions in the context of bioenergy systems and they can make complexities and value conflicts more transparent for debate and policy-making [40].

Decision-making about sustainability could benefit from combined approaches that apply environmental, economic and social assessment methods in addition to life cycle assessment [41]. Very similarly to sustainability management and assessment approaches, circular economy implementation requires simultaneous focus on limited natural resources, environmental concerns, business aspects and social awareness [42].

Additionally, previous studies have concluded that corporate sustainability requires integrative measurement and management of sustainability issues instead of isolated application of various tools [6,7]. Sustainability performance indicators can be applied to the identification and assessment of key issues [6] and sustainability assessment and management accounting, control, and reporting should be integrated [7]. Studies in the field of sustainable buildings have noted the importance of systematic and holistic sustainability assessment using environmental, social and economic criteria with due focus on social sustainability aspects and support of informed decision-making [12-14].

In the biorefinery case, it is noteworthy that the planned biorefinery will utilize the most modern techniques and therefore its emissions are likely to be significantly lower than the Best Available Techniques (BAT) values in the reference documents (BREFs). Moreover, social aspects can be taken better into account in the planned new biorefinery than in older plants provided that these issues are duly addressed. In the slag processing case, the perceived unfair competition situations created by international, EU level and national legal environments lowered the score in the legal aspects indicator. Full realization of all these positive developments off course requires both management awareness of sustainability issues and public sector steering.

Circular economy development is given particular emphasis on this study because of its timely importance at the EU, national and regional levels. Contemporary EU policy goals highlight the importance of circular economy encompassing focus on sustainability considerations, life cycle thinking, whole system apprpaches, resource efficiency and resource productivity in industry [12-14]. In the Finnish Lapland, there have been a lot of efforts to establish a functioning cluster of arctic industry with emphasis on circular economy development, sustainability and industrial ecosystems and symbiosis [15-18]. National efforts highlight, for example, the advancement of more sustainable societies and businesses considering economic, environmental and societal aspects [19] taking into account e.g., the value of production side streams and creation of cooperation between industry and small and medium-sized enterprises [20]. Previous studies on circular economy have suggested that it can advance sustainable development, inter-industry integration and cleaner production [21] and that performance indicators can be applied to the identification and assessment of key issues [22]. The balancing economic, environmental and societal aspects in the context of circular economy is important and the transition towards circular economy is about engagement of all societal actors based on an interdisciplinary framework and addressing problems such as inefficient resource use, environmental impacts and social inequity [23].

One of the limitations of the developed approach and the obtained results is that it is impossible to consider trade-offs between and cross-effects of different sustainability dimensions. This problematic was also noted in a previous study on sustainability assessments and associated three dimensions [43]. In addition, the index approach is qualitative and it has limitations, such as the relative roughness of the scoring and lack of numerical data. The idea was to design and implement a simple and a balanced approach to both developing and assessing sustainability performance in arctic process industry based on a collaborative development process.

Regarding expected effects of the planned biorefinery investment on the regional economy, the results of the previous study on the old Kemijärvi pulp mill also indicated the importance of the mill for the region of Eastern Lapland. For example, the GDP would have been much lower and the unemployment rate much bigger without the factory [44]. Honkatukia has also evaluated the 
effects of closure of the old Kemijärvi pulp mill in 2008 (not published) to support governmental decision-making and those findings indicated the value chains of the Kemijärvi region to be very dependent on regional use of wood. In this study, the effects are in many ways a mirror image to the previous study with one exception: the almost decade-long slump in the local use of wood has had an adverse impact on the state of regional forests. It appears not unrealistic to expect that the revival of forest industries would improve the state of the local forests by creating incentives for forestry.

Suggestions for future research on sustainability performance and assessment in process industry encompass the following key focus areas: (1) specific sustainability strategies, management approaches and reporting frameworks; (2) balanced approaches to supply chain sustainability; (3) wider societal and economic impacts; (4) social due diligence and (5) greenhouse gas emissions (monitoring and assessment). Additionally, cross-effects and trade-offs in this context are an interesting line of further research.

\section{Conclusions}

This study aimed at building capacity for and piloting of sustainability assessment in arctic process industry covering two cases studies. As a result, the novel sets of environmental and economic sustainability performance and assessment indicators were developed and the previously developed social indicator set was updated. The results of the pilot testing indicate high level of sustainability performance in both cases. However, sustainability performance was lower in the supply chain, greenhouse gas emissions (monitoring and assessment) and specific sustainability management and reporting approaches categories as well as regarding some aspects of code of conduct, life cycle thinking and training (circular economy). Some of these issues were also identified in our previous study on social sustainability performance in process industry. Thus, it can be recommended that further research should be focused on these areas including development of more detailed performance metrics considering cross-effects, trade-offs and the potential to utilize numerical data based on continuous monitoring. Other interesting areas that could benefit from further research encompass differences in practices in different market areas, research and development on sustainability and possible situations of unfair competition created by legal frameworks at various levels. Regarding the nature of sustainability and associated assessments, it is always good to remember that these are complex and diverse topics that are impacted multiple dynamic drivers that change in time and place. Thus, the results presented here represent our best efforts at the time to carry out a balanced and holistic assessment using the described methodology taking into account its limitations. The expected positive effects on the regional economy in Lapland were also noteworthy. Remarkably, a large part of the impact on the regional economy is created in the local raw material and logistic value chains of the plant. This appears to be typical of the Finnish bioeconomy and distinguishes the sector from many other industrial sectors, which rely much more extensively on imported intermediate goods and raw materials.

Acknowledgments: This study was carried out within the Arctic Business Concept project which is funded by the Regional Council of Lapland and has almost all municipalities in Lapland as partners. The project was supported by the European Regional Development Fund.

Conflicts of Interest: The authors declare no conflict of interest.

\section{Appendix A}

Table A1. Examples of sub-indicators addressing environmental impacts.

\begin{tabular}{clcr}
\hline Indicator & \multicolumn{1}{c}{ Example 1 } & Example 2 & Example 3 \\
\hline Water Emissions & Total Phosphorus (P) & Total Nitrogen (N) & Chemical Oxygen Demand (COD) \\
\hline Solid residues & $\begin{array}{l}\text { Quality and amount of residue } \\
\text { streams }\end{array}$ & Landfilled waste & Recycling/utilization/reuse rates \\
\hline $\begin{array}{c}\text { Process and production } \\
\text { efficiency }\end{array}$ & $\begin{array}{l}\text { Consumption and production of } \\
\text { electricity and heat energy }\end{array}$ & $\begin{array}{l}\text { Share of renewable energy } \\
\text { (production and consumption) }\end{array}$ & $\begin{array}{l}\mathrm{CO}_{2} \text { emissions (purchased energy } \\
\text { and own production/consumption) }\end{array}$ \\
\hline
\end{tabular}


Table A1. Cont.

\begin{tabular}{|c|c|c|c|}
\hline Indicator & Example 1 & Example 2 & Example 3 \\
\hline Greenhouse gas emissions & Process emissions & $\begin{array}{l}\text { Emissions from raw materials } \\
\text { production }\end{array}$ & $\begin{array}{l}\text { Reduction of greenhouse gas } \\
\text { emissions }\end{array}$ \\
\hline Water Emissions & Total Phosphorus (P) & Total Nitrogen (N) & Chemical Oxygen Demand (COD) \\
\hline Environmental innovations & $\begin{array}{l}\text { Innovations to reduce greenhouse } \\
\text { gas emissions from production, } \\
\text { processes and operations (within } \\
\text { last } 3 \text { years) }\end{array}$ & $\begin{array}{l}\text { Innovations to reduce } \\
\text { greenhouse gas emissions from } \\
\text { products (within last } 3 \text { years) }\end{array}$ & $\begin{array}{l}\text { Innovation to reduce supply chain } \\
\text { and/or customer greenhouse gas } \\
\text { emissions }\end{array}$ \\
\hline Legal aspects & $\begin{array}{l}\text { Detailed zoning plan for the } \\
\text { operations area (location of } \\
\text { operations is allowed there) }\end{array}$ & $\begin{array}{l}\text { Requirement for an } \\
\text { environmental permit and } \\
\text { environmental impact } \\
\text { assessment for operations }\end{array}$ & $\begin{array}{l}\text { Monitoring by and regular reporting } \\
\text { to authorities }\end{array}$ \\
\hline
\end{tabular}

\section{References}

1. United Nations. Transforming Our World: The 2030 Agenda for Sustainable Development. 2015. Available online: https:/ / sustainabledevelopment.un.org/post2015/transformingourworld (accessed on 25 May 2017).

2. Azapagic, A. Developing a framework for sustainable development indicators for the mining and minerals industry. J. Clean. Prod. 2004, 12, 639-662. [CrossRef]

3. Azapagic, A.; Perdan, S. An integrated sustainability decision-support framework, Part 1-Problem structuring. Int. J. Sustain. Dev. Ecol. 2005, 12, 98-111. [CrossRef]

4. Singh, R.K.; Murty, H.R.; Gupta, S.K.; Dikshit, A.K. Development of composite sustainability performance index for steel industry. Ecol. Indic. 2007, 7, 565-588. [CrossRef]

5. Singh, R.K.; Murty, H.R.; Gupta, S.K.; Dikshit, A.K. An overview of sustainability assessment methodologies. Ecol. Indic. 2012, 15, 281-299. [CrossRef]

6. Maas, K.; Schaltegger, S.; Crutzen, N. Integrating corporate sustainability assessment, management accounting, control, and reporting. Special Volume: The Integration of Corporate Sustainability Assessment, Management Accounting, Control, and Reporting. J. Clean. Prod. 2016, 136, 237-248. [CrossRef]

7. Maas, K.; Schaltegger, S.; Crutzen, N. Advancing the integration of corporate sustainability measurement, management and reporting. J. Clean. Prod. 2016, 133, 859-862. [CrossRef]

8. Seuring, S.; Gold, S. Sustainability management beyond corporate boundaries: From stakeholders to performance. Special Volume: Sustainability management beyond corporate boundaries. J. Clean. Prod. 2013, 56, 1-6. [CrossRef]

9. Haapio, A.; Viitaniemi, P. A critical review of building environmental assessment tools. Environ. Impact Assess. Rev. 2008, 28, 469-482. [CrossRef]

10. Sierra, L.A.; Pellicerb, E.; Yepesc, V. Method for estimating the social sustainability of infrastructure projects. Environ. Impact Assess. Rev. 2017, 65, 41-53. [CrossRef]

11. Mateus, R.; Braganca, L. Sustainability assessment and rating of buildings: Developing the methodology SBTool PT-H. Build. Environ. 2011, 46, 1962-1971. [CrossRef]

12. Communication from the Commission to the European Parliament, the Council, the European Economic and Social Committee and the Committee of the Regions. Towards a Circular Economy: A Zero Waste Programme for Europe. COM/2014/0398 Final. Available online: http:/ / eur-lex.europa.eu/legal-content/ EN/TXT/?uri=CELEX:52014DC0398R(01) (accessed on 25 May 2017).

13. European Commission. Circular Economy. 2017. Available online: http:/ / ec.europa.eu/environment/circu lar-economy/index_en.htm (accessed on 25 May 2017). 
14. Communication from the Commission to the European Parliament, the Council, the European Economic and Social Committee and the Committee of the Regions. Closing the Loop-An EU Action Plan for the Circular Economy. COM (2015)614 Final. Available online: http:/ / eur-lex.europa.eu/legal-content/EN/T XT/?uri=CELEX:52015DC0614 (accessed on 25 May 2017).

15. Norden-Nordic Council of Ministers. Nordic Bioeconomy 25 Cases of Sustainable Change. 2017. Available online: http://norden.diva-portal.org/smash/get/diva2:1065456/FULLTEXT01.pdf (accessed on 25 May 2017).

16. Lapin Luotsi. Regional Council of Lapland: Foresight Work in Lapland. 2016. Available online: http:/ /luotsi.lappi.fi/arctic-industry-and-circular-economy (accessed on 25 May 2017).

17. Green Growth in Nordic Regions-50 Ways to Make It Happen. Nordregio, 2016. Available online: http:/ / www.nordregio.se/en/Publications/Publications-2016/GREEN-GROWTH-IN-NORDIC-REGI ONS-50-ways-to-make-it-happen/Circular-economy-/ An-ecosystem-of-arctic-industries-in-Kemi-Torn io- / (accessed on 25 May 2017).

18. European Cluster Observatory (ECO). Newsletter. 2014. Available online: http:/ /ec.europa.eu/DocsRoom/ documents/16524/attachments/1/translations/en/renditions/pdf (accessed on 25 May 2017).

19. Sitra Studies 121. Leading the Cycle-Finnish Road Map to a Circular Economy 2016-2025. 2016. Available online: http:/ / www.sitra.fi/sites/default/files/sitra_leading_the_cycle_report.pdf (accessed on 25 May 2017).

20. Sitra Studies 100. The Opportunities of a Circular Economy for Finland. 2015. Available online: https:/ / media.sitra.fi/2017/02/28142449/Selvityksia100.pdf (accessed on 25 May 2017).

21. Li, Y.; Ma, C. Circular economy of a papermaking park in China: A case study. J. Clean. Prod. 2015, 92, 65-74. [CrossRef]

22. Su, B.; Heshmati, A.; Geng, Y.; Yu, X. A review of the circular economy in china: Moving from rhetoric to implementation. J. Clean. Prod. 2013, 42, 215-227. [CrossRef]

23. Ghiselli, P.; Cialani, C.; Ulgiati, S. A review on circular economy: The expected transition to a balanced interplay of environmental and economic systems. J. Clean. Prod. 2016, 114, 11-32. [CrossRef]

24. Boreal Bioref Biorefinery. 2017. Available online: http:/ / www.borealbioref.fi/en/ (accessed on 11 July 2017).

25. Tapojärvi Oy. 2017. Available online: http://www.tapojarvi.com/en/services/factory-services/valorisatio n-of-stainless-steel-slag.html (accessed on 11 July 2017).

26. Husgafvel, R.; Pajunen, N.; Dahl, O.; Heiskanen, K.; Ekroos, A.; Virtanen, K. Development of Environmental and Economic Sustainability Metrics for the Metal Production Industry-Experiences From University-Industry Cooperation. Front. Sustain. 2017. Available online: http://www.mdpi.com/books/pdf download/article/349/1 (accessed on 20 September 2017). [CrossRef]

27. Husgafvel, R.; Pajunen, N.; Päällysaho, M.; Paavola, I.-L.; Inkinen, V.; Heiskanen, K.; Dahl, O.; Ekroos, A. Social metrics in the process industry-Background, theory and development work. Int. J. Sustain. Eng. 2014, 7, 171-182. [CrossRef]

28. Husgafvel, R.; Pajunen, N.; Virtanen, K.; Paavola, I.-L.; Päällysaho, M.; Inkinen, V.; Heiskanen, K.; Dahl, O.; Ekroos, A. Social sustainability performance indicators-Experiences from process industry. Int. J. Sustain. Eng. 2015, 8, 14-25. [CrossRef]

29. The Worldwide Governance Indicators; Description of Methodology; The World Bank: Washington, DC, USA, 2017; Available online: http:/ /info.worldbank.org/governance/wgi/\#doc (accessed on 25 May 2017).

30. Sweco. Boreal Bioref Oy, Kemijärven Biojalostamon Ympäristövaikutusten Arviointiohjelma. 2016. Available online: http:/ / www.ymparisto.fi/download/noname/\%7B358D9024-B7E8--452E-8D4A-25430A1B1145 \%7D/121117 (accessed on 25 May 2017).

31. Honkatukia, J. The VATTAGE Regional Model VERM: A Dynamic, Regional, Applied General Equilibrium Model of The Finnish Economy; VATT Research Reports No. 171; Government of the Republic of Finland-Government Institute for Economic Research (VATT): Helsinki, Finland, 2013.

32. De Vet, J.M.; Roy, S.; Schneider, H.; Thio, V.; van Bork, G. Review of Methodologies Applied for the Assessment of Employment and Social Impacts; IZA Research Report No. 28; ECORYS Brussels NV: Brussels, Belgium, 2010.

33. Bergström, O.; Broughton, A.; Triomphe, C.E. EU Synthesis Report, 27 National Seminars, Anticipating and Managing Restructuring; European Commission: Brussels, Belgium, 2010.

34. Arodudu, O.; Helming, K.; Wiggering, H.; Voinov, A. Towards a more holistic sustainability assessment framework for agro-bioenergy systems-A review. Environ. Impact Assess. Rev. 2017, 62, 61-75. [CrossRef] 
35. Chen, D.; Thiede, S.; Schudeleit, T.; Herrmann, C. A holistic and rapid sustainability assessment tool for manufacturing SMEs. CIRP Ann. 2014, 63, 437-440. [CrossRef]

36. Santoyo-Castelazo, E.; Azapagic, A. Sustainability assessment of energy systems: Integrating environmental, economic and social aspects. J. Clean. Prod. 2014, 80, 119-138. [CrossRef]

37. Mayer, A.L. Strengths and weaknesses of common sustainability indices for multidimensional systems. Environ. Int. 2008, 34, 277-291. [CrossRef] [PubMed]

38. Parahelia, R.; Dalgaard, T.; Jørgensen, U.; Adamsen, A.P.S.; Knudsen, M.T.; Birkved, M.; Gylling, M.; Schjørring, J.K. Biorefining in the prevailing energy and materials crisis: A review of sustainable pathways for biorefinery value chains and sustainability assessment methodologies. Renew. Sustain. Energy Rev. 2015, 43, 244-263. [CrossRef]

39. Evans, A.; Strezov, V.; Evans, T.J. Assessment of sustainability indicators for renewable energy technologies. Renew. Sustain. Energy Rev. 2009, 13, 1082-1088. [CrossRef]

40. Raman, S.; Mohr, A.; Helliwell, R.; Ribeiro, B.; Shortall, O.; Smith, R.; Millar, K. Integrating social and value dimensions into sustainability assessment of lignocellulosic biofuels. Biomass Bioenergy 2015, 82, 49-62. [CrossRef] [PubMed]

41. Jeswani, H.K.; Azapagic, A.; Schepelmann, P.; Ritthoff, M. Options for broadening and deepening the LCA approaches. J. Clean. Prod. 2010, 18, 120-127. [CrossRef]

42. Lieder, M.; Rashid, A. Towards circular economy implementation: A comprehensive review in context of manufacturing industry. J. Clean. Prod. 2016, 115, 36-51.

43. Morrison-Saunders, A.; Pope, J. Conceptualizing and managing trade-offs in sustainability assessment. Environ. Impact Assess. Rev. 2013, 38, 54-63. [CrossRef]

44. Honkatukia, J.; Törmä, H. Stora Enso Oyj:n Kemijärven Sellutehtaan 40-Vuotisen Toiminnan Alueellinen Kokonaisvaikuttavuus; Translated by Government Institute for Economic Research; Valtion Taloudellinen Tutkimuskeskus (VATT): Helsinki, Finland, 2005.

(C) 2017 by the authors. Licensee MDPI, Basel, Switzerland. This article is an open access article distributed under the terms and conditions of the Creative Commons Attribution (CC BY) license (http://creativecommons.org/licenses/by/4.0/). 